\title{
Traditional Cardiopulmonary Criterion of Death is the Only Valid Criterion of Human Death
}

\author{
PETER VOLEK \\ Catholic University in Ružomberok \\ Slovakia \\ peter.volek@ku.sk \\ ORCID: 0000-0002-9119-962X
}

\begin{abstract}
In recent time the critique of the whole brain death as the criterion of human death, that was introduced in 1968, has been growing. The paper aims to show in systematically that there are good reasons based on empirical findings combined with Thomistic Christian anthropology to accept the traditional cardiopulmonary criterion as the criterion of human death. This will be shown through a systematic critique of other criteria of death: whole brain death, higher brain death, brain stem death, and controlled cardiac/circulatory death. The traditional cardiopulmonary criterion of death provides the opportunity to maintain the dead donor rule for organ transplantation. This also affirms the respect for human life required by the ethics of the sanctity of human life. The paper further provides a justification of dead donor rule. The paper proposes 35 minutes period after cardiac arrest to declare the patient dead, since at that time there is no possibility to autoresuscitate the heart.
\end{abstract}

Keywords: human death; criterion od death; cardiopulmonary criterion of death; whole brain death; higher brain death; dead donor rule. 


\section{Introduction}

Humans have always been intrigued by the question of when a man is still alive and when (s)he can be considered dead. With the development of science, technology, and medicine, this question has become even more pressing. "At the end of the last century, a new definition of death was introduced. In the past, the irreversible loss of heart and lung functions had signaled death. The new definition was based on the irreversible loss of brain functions. The transition from the heart to brain grew out of several parallel developments that converged in 1968... It began in 1947 when Claude Beck performed the first successful defibrillation of a human heart. Suddenly, death was 'reversible.' In 1950, Bower and Bennett developed positive pressure ventilation.” (De Georgia 2014, 673). It was not clear when a patient is dead. A patient with a respirator could breathe without any brain activity. Was (s)he alive or not? A new definition of death, which is also called neurological, was not accepted by all physicians or philosophers. The controversy remains until the present. In this paper, I try to defend the thesis that the traditional cardiopulmonary criterion of death is the only valid criterion of human death. To support this thesis, I will use the argument confirmed by several empirical cases. The paper will also provide the justification of the dead donor rule and propose a minimum of 35 minutes after asystole required to declare a patient dead.

\section{The history of the concept of brain death}

When considering the history of the concept of brain death, it is often argued that its contemporary meaning was first described in the definition of the irreversible coma introduced by Harvard Medical School in 1968 to gain organs for transplantation (Jonas, 1974). ${ }^{1}$ Let us briefly have a look at the history of

1 Robert Truog speaks of the procurement of organs for transplantation as an important factor in the introduction of the brain death criterion (Truog, 2007, 280). Schiff a Fins speak of the first mention of brain death in Ad Hoc Committee of Harvard Medical School 1968 (Schiff and Fins, 2016, R572). 
this concept to see how much can be accepted by this meaning. The concept was first used in 1800 by Xavier Bichat in his work Recherches physiologiques sur la vie et la mort. He understood brain death as a local cessation of the neural area of life while other local areas of life are still preserved for a longer or shorter period of time (Métraux, 2001, Volek, 2009, 23). The concept of brain death in its current meaning started to evolve independently of the issue of the procurement of organs for transplantation. Organ transplantation has been made possible by technological advances and the invention of immunosuppressives. The concept of brain death in its current meaning was made possible by the developments in intensive care (Machado, 2007, ch. 1). ${ }^{2}$ The concept of brain death in its current meaning as the criterion of death started to evolve in 1952 in Ibsen's publications, who had started to use mechanical ventilation for breathing and ended in the formulation of brain death in the current meaning by Wertheimer in 1960. The concept was then connected with the issues pertaining to mechanical ventilation and the continuation of intensive care without yet any connection with the issues pertaining to transplantations (Machado et al., 2007; De Georgia, 2014; Moskopp, 2017). In 1963 in Louvaine, Belgian surgeon Guy Alexander performed the first transplantation based on the criterion of brain death then referred to as deep coma. Alexander talked about this procedure at a CIBA Symposium on Transplantation in London in March 1966 (Machado, 2005). Brain death as a criterion of death during reanimation and employment of technical means when one cannot use the criterion of cessation of breathing and blood circulation was suggested by the Committee for reanimation and transplantations of the German Surgeon Society in 1968. They also proposed signs characterizing brain death (Kommission, 1968).

On August 5, 1968, in its report entitled The definition of irreversible coma the Ad Hoc Committee of the Harvard Medical School determined irreversible coma as a new criterion of death and also specified the conditions for determining brain death (Ad Hoc Committee, 1968). That same

2 Calixto Machado is a proponent of the definition of death as the irreversible loss of consciousness (Machado, 2007, 200-201), which puts him among the proponents of the higher brain death criterion. 
day, whole brain death (WBD) was accepted as a criterion of death at the $22^{\text {nd }}$ Congress of the World Medical Association (Gilder, 1968; De Georgia, 2014, 675). The main interest of the members of the Ad Hoc Committee was to redefine the criterion of death to obtain organs for transplantation (Giacomini, 1997). The Harvard Medical School Ad Hoc Committee's report was still criticized for an unprecise terminological definition of brain death (Jonas, 1974). Further publications tried to address these shortcomings.

Leon R. Kass defined death as the disintegration of an integrated whole and an event (Kass, 1971). In 1972 Capron and Kass suggested there are four levels of argumentation concerning the death of a human being and proposed a definition of human death (Capron and Kass, 1972, 102-103). The first level is the level of basic concept. It is the definition of death. One type of definition they suggest is the "permanent cessation of the integrated functioning of an organism as a whole" (Capron and Kass, 1972, 102). ${ }^{3}$ The second level is the level of general physiological standards that include the criteria of human death. The third is the level of operational criteria that further define what is meant by the operational standards. The fourth level is the level of specific tests or procedures for determining whether the criteria have been met. The second level is to be used for the purposes of legislation. The first is too general and it would be too complicated to solve the conflict between the various views. The third and fourth levels are too specific and connected with the results of empirical sciences that undergo constant development (Capron and Kass, 1972, 103).

Bernat, Culver and Gert suggested three levels of argumentation pertaining to the determination of human death, viz. definition, criteria, and testing (Bernat, Culver and Gert, 1981) that are also accepted by Shewmon (2010, 278-281). They thus connect Capron and Kass' third and fourth

\footnotetext{
This definition is accepted by many influential authors and gremia: Bernat, Culvert and Gert, 1981, 390; President's Commission for the Study of Ethical Problems in Medicine and Biomedicine and Behavioral Research, 1981, 58; National Conference of Commissioners of Uniform State Laws, 1980; Bernat, 1998, 17; Bernat, 2006, 38; President's Council on Bioethics, 2008, 59-64. Shewmon $(2001,458)$ equates the understanding of the cessation of integrated functioning as a whole with somatic integration; this position is criticized by the President's Council on Bioethics (2008, 59-65).
} 
level into one level and moved the cardio-pulmonary criterion to the level of testing as a way of determining when the whole brain function ceased (Khushf, 2010, 336). It is more appropriate to distinguish the four levels since it is more precise. Capron and Kass also suggested a detailed definition of the criterion of death, which they located to the second level of the general physiological standards. Death is determined by a physician upon the irreversible cessation of the spontaneous respiratory and circulatory functions. If these functions are preserved by artificial means, the physician determines death based on the irreversible cessation of spontaneous brain functions (Capron and Kass, 1972, 111).

These suggestions also influenced the definitions of the President's Commission for the Study of Ethical Problems in Medicine and Biomedicine and Behavioral Research (1981) that already defined them as two equal criteria without the specification of circumstances when they are to be used. This commission also formulated two possible interpretations of these criteria. ${ }^{4}$ One of these interpretations gives priority to WBD and the cardio-pulmonary criterion becomes a test when the function of the whole brain is irreversibly lost since the brain tissue is bound to die if not supplied with blood. The second interpretation commences with the cardio-pulmonary criterion. New technologies mask the effects of death through the support of breathing. Both these criteria are the criteria of one phenomenon of death (President's Commission, 1981, 6, 32-38, ch. 3, 5). Bernat (1998) prefers the first interpretation. Kass (Kass, 1971) and Capron (Capron and Kass, 1972, 111), and the President's Council on Bioethics (2008) prefer the second. President's Commission (1981) and the President's Council (2008) define the integrating function of an organism as a whole via the integrating effect of the brain, heart, and lungs. Other authors specify just the brain as the integrating organ (Bernat, Culver and Gert, 1981, 391). The President's Commission (1981) agrees with the suggestion of Capron and Kass to define death at the second level of argumentation (56).

After approval of the Universal Determination of Death Act (UDDA) drafted by the National Conference on Commissioners of Uniform State Laws and

4 For more on these interpretations see Khushf, 2010. 
approved by American Medical Association on October 19, 1980, and by the American Bar Association on February 10, 1981, the formulation of the death criteria as WBD or irreversible cessation of heartbeat and blood circulation (IHB\&BC) were legally accepted in many states of the USA and many countries in the world.

In its statement from December 2008 published under the title Controversies in the Determination of Death. A White Paper by the President's Council on Bioethics, the President's Council on Bioethics in the USA decided to support WBD as the death criterion, even though it gave it a new name the total brain failure. Until then, the functioning of the human organism as a whole was understood as the functioning of an organism whose parts cooperate in an integrating manner. However, even in some cases of WBD, some body parts kept functioning in an integrating manner, that some can take to be as the functioning of an organism as a whole. The White Paper, thus, suggested a new definition of the failure of an organism to function as a whole, based on the failure of self-preservation of an organism in contact with the surrounding world. It explains the contact of an organism with the surrounding world through three fundamental capacities:

"1. Openness to the world, that is receptivity to stimuli and signals from the surrounding environment.

2. The ability to act upon the world to obtain selectively what it needs.

3. The basic felt need that drives the organism to act as it must, to obtain what it needs and what its openness reveals to be available." (President's Council, 2008, 61).

The openness to the world is manifested in the consciousness of awareness at least in a rudimentary form. The vegetative state patients (VSP) have spontaneous breathing, which manifests the need to breathe and thus gain what the organism needs. Patients with certain forms of brain damage can have their ability to breath impaired but preserve their consciousness. If there are no signs of consciousness and spontaneous breathing is absent, and both these conditions are irreversible, it is a sign that the organism as a whole ceased to function. (President's Council, 2008, 59-64). 
In 1990, The German Bishops' Conference together with the Council of the Evangelical Church in Germany supported WBD combined with IHB \&BC to be the criterion of human death. When the brain dies the basis for the spiritual existence of a person in the world vanishes. Without brain, a person cannot perceive, express herself, make decisions. Besides that, the brain integrates the organs into one organism as a whole. (Erklärung, 1990, 17-18). However, Cardinal Meisner from Köln was against the acceptance of WBD as the criterion of death of man (Meisner, 1996, Nr. 316). In 2015 in its most recent statement, the German Bishops' Conference supports WBD as the death criterion (Die Deutschen Bischöfe, 2015). This statement also reacts to the White Paper of the President's Council on Bioethics from 2008. The German Bishops stress the role of the dead donor rule (DDR) in the process of unpaired vitally essential organ donations. They emphasize that already in 1993 the German Medical Association's support of WBD as the criterion of human death includes not only brain's role in the somatic integration, but also its importance for other functions as autonomy, coordination, spontaneity, and the reaction of the organism as a whole towards the surrounding world.

The case of Jahi McMath provides an opportunity to introduce the issue of brain death to the public. In December 2013, Jahi McMath clearly fulfilled the criteria for WBD (Shewmon, 2018). She was on a ventilator, but her family did not approve her removal. In early 2014, her family reported that Jahi began to respond to simple motor commands. Her family began to make video recordings of these responses. In September 2014, MRI at Rutgers University Hospital showed extensive damage to white matter of the brain stem, but the preservation of the cerebral hemispheres, flat EEG and no responses to evoked potentials. Calixto Machado found electrocerebral activity on EEGs performed at other times. "Jahi continued to sexually mature after her diagnosis of brain death and menstruated. This implies intact hypothalamic and pituitary functions which are functions of the brain" (McGee and Gardiner, 2019, 2). Jahi McMath passed away on June 22, 2018. According to Shewmon, since early 2014, she was in a minimal conscious state (Shewmon, 2018, S75), according to Machado et al. she was neither 
in a minimal conscious state nor brain dead, she was "in a state of disorder of consciousness, not previously described" (Machado et al., 2018, 521; Machado, 2019). This case shows that neurologic criterion (WBD) cannot be a sign of death, or that the standards for WBD cannot meet the UDDA's requirement that death is the irreversible cessation of all brain functions.

\section{Five basic conceptions in the determination of human death}

At present, there are five basic positions on the issue of determining when a man can be considered dead - what is the appropriate criterion of human death. The first maintains that death occurs with the whole brain death. WBD refers to the failure and irreversible cessation of all functions of the entire brain. The most prominent proponents of this view are James L. Bernat (Bernat, 1998, 2006; Bernat, Culver and Gert, 1981), Eelco F. M. Wijdicks (2001), Patrick Lee and German Grisez (Lee and Grisez, 2012). The second position argues that death occurs with higher brain death (HBD). HBD refers to the irreversible cessation of those brain functions that are required for thinking, reasoning, decision making, and other manifestations of human consciousness. The most prominent proponents of this criterion are e.g. Robert Veatch (2005), Jeff McMahan (2006), Robert Truog (2007), Calixto Machado (2007, 200-201), ${ }^{5}$ John P. Lizza (2018), Peter Singer (2018). ${ }^{6}$ The

5 I infer this from his definition of death as the loss of consciousness (Machado, 2007, 200), later he supports WBD (Machado, 2019).

6 Peter Singer holds that HBD is the death of a person, but not the biological death of a man (Singer, 2018). This is based on his preference utilitarianism, his Lockean concept of person understood as a rational and self-aware being (Singer, 2011, 74-75), and his view of the equality of all animals. Singer's preference utilitarianism is grounded in the preferences. Preference utilitarianism "holds that we should do what, on balance, furthers the preferences of those affected." (Singer, 2011, 13) More precisely, "preferences that should be counted ... are those that we would have if we were fully informed, in a calm frame of mind and thinking clearly.” (Singer, 2011, 14) According to Peter Singer, all animals including humans are equal, which is grounded in their capacity to suffer (Singer, 1974). The equality of all humans and all animals is founded on the principle of equal consideration of interests (Singer 2011, 16-70). All animals including humans wish to experience happiness and avoid suffering. According to preference utilitarianism there is a distinc- 
third view holds that human death occurs with the irreversible cessation of heartbeat and blood circulation (IHB\&BC). The most prominent proponent of this view is D. Alan Shewmon (Shewmon, 1997, 1998a, 1998b, 2001, 2010), ${ }^{7}$ others are e.g. Josef Seifert (1993), Nicanor Austriaco (2003), John Finnis (2011), David Albert Jones (2012) and Doyen Nguyen (2016, 2017, 2018a, 2018b, 2019). The fourth position specifies that death occurs with brain stem death (BSD). It has been defended e.g. by Christopher Pallis (Pallis, 1982, 1995, 1999) and D. Gardiner, et al. (2012, i14). BSD criterion was accepted into guidelines on the diagnosis of brain (stem) death published by the United Kingdom Conference of Medical Royal Colleges and their Faculties in 1976 and remains the basis for practice in the United Kingdom until today (Smith, 2015). Similarly, in Canada, there is no statutory definition of death. In 2003 The forum of medical experts in Vancouver recommended BSD as the definition of death (Shemie et al., 2006, S3). Laws in India recognize BSD or cardiopulmonary death (Vadi and Shroff, 2019, 368). A forum of medical experts in collaboration with the World Health Organization formulated a definition of death that is in its essence a recapitulation of the UK definition (Shemie et al., 2014, 794), in which the meaning of "permanent" is adopted from Bernat et al. (2010, 964-965). The fifth position specifies that

tion "between self-aware individuals, leading their own lives and wanting to go on living, and those with no future-directed preferences." (Singer, 2011, 111) Hence, according to Singer, it is necessary to distinguish "between killing those who are rational and self-conscious and killing those who are not" (Singer, 2011, 111). In his book Rethinking Life and Death, Peter Singer expresses his view that the concept of brain death was invented to obtain organs for organ transplantation and to withdraw medical treatment in hopeless cases. At the time, the standard sets of tests did not show an irreversible cessation of all functions of the brain. Legal definitions and medical practice have, thus, come apart. Singer suggests adjusting the definition of death (Singer 1994, ch. 2). According to Singer and his preference utilitarianism, "an action contrary to the preference of any being is wrong, unless this preference is outweighed by contrary preferences. Killing a person who prefers to continue living is therefore wrong, other things being equal." (Singer, 2011, 80). According to Singer, embryos, fetuses and newborns have no interests. Thus, if their relatives do not want them to live, abortion and infanticide are permissible (Singer, 2011, 154). Singer justifies voluntary euthanasia on the grounds of respect for the preferences and clear rational basis for the decision itself, and involuntary euthanasia only if it can prevent torture or worse evil (Singer, 2011, 176-178).

7 Shewmon first used to hold HBD (Shewmon, 1985), but in 1997 he abandoned his position in favor of IHB\&BC and developed a critique of WBD (Shewmon, 1997). 
death occurs after the cessation of heartbeat and blood circulation. This criterion is sometimes called controlled cardiac/circulatory death (CC/CD) (Nguyen 2018a, 111-139). It has been introduced by the Pittsburgh Protocol in 1992 (University of Pittsburgh Medical Center, 1993). The most prominent proponents of this criterion are James Bernat and Alexander Capron since 2006 (Bernat, 2008; Bernat, et al., 2006; Bernat, Capron et al. 2010), David J. Cole (1992, 1993), James DuBois (1999).

Moreover, there are authors, who combine WBD and IHB\&BC arguing that sometimes death can be pronounced given the irreversible cessation of all functions of the entire brain, at other times given the irreversible cessation of the circulatory system. This view is defended e.g. by Capron and Kass (1972), President's Commission for the Study of Ethical Problems in Medicine and Biomedical and Behavioral Research 1981, Eelco F. M. Wijdicks (2006), George Khushf (2010), and Daniel P. Sulmasy (2019). ${ }^{8}$ The combination of WBD and IHB\&BC criteria has been accepted into the legislation of many countries. Some authors combine WBD and CC/CD (e.g., Doran and Vukov, 2019).

This article provides a set of reasons in favor of accepting the IHB\&BC criteria and also argues that we need to adopt and follow DDR. I will focus on defending these views by providing positive reasons in their favor and also by refuting the critique developed against them by other authors.

\section{Reasons for the traditional cardiopulmonary death as the only valid criterion of the human death}

In the history of medicine and bioethics, five criteria of human death were occurred: (i) the traditional cardiopulmonary criterion; (ii) the wholebrain death; (iii) the higher brain death; (iv) the brain stem death, (v) the controlled cardiac/circulatory death. In this chapter, I will argue that the

8 Sulmasy admits that some patients with WBD are still alive. He proposes more precise tests for WBD "through inclusion of evidence of more cerebro-somatic disintegration (e.g., hypothalamic or neuroendocrine dysregulation)” (Sulmasy, 2019, 479). 
whole brain death, the higher brain death, the brain stem death and the controlled cardiac/circulatory death are not criteria of human death.

\section{(1) Whole brain death}

After given rationale through Bernat, Culver and Gert (1981) and its acceptance through President's Commission for the Study of Ethical Problems in Medicine and Biomedical and Behavioral Research (1981), and by the formulation of UDDA through National Conference on Commissioners of Uniform State Laws, which was approved 1981, WBD (or IHB\&BC) was approved by laws in many states of the USA and throughout the world. WBD was not accepted by some prominent philosophers and physicians, e.g. Hans Jonas (1974), D. Alan Shewmon (1997, 1998a, 1998b, 2001, 2010), Nicanor Austriaco (2003), Robert Truogh (2007), John Finnis (2011) ${ }^{9}$, David Albert Jones (2012), Michel Accad (2015), Doyen Nguyen (2016, 2017, 2018a, 2018b, 2019), David S. Oderberg (2019). The main reason for rejection WBD is given by empirical findings interpreted in the light of Thomistic anthropology, the main features of which are accepted in the teaching of the Catholic Church. The arguments for WBD are based on three main presuppositions: (1) brain is the main integrator of the human organism (Accad, 2015), (2) a living body after determining WBD is not a human body (Accad, 2015), (3) the loss of psycho-physical integration needed for the reaction to outer stimuli (Gligorov, 2016), which is constituted by the loss of spontaneous breathing together with the loss of the bodily integration, and the loss of the psychological integration. The first presupposition is maintained by e.g. Bernat, Culver and Gert (1981) and Moschella (2019). But it is empirically untenable. This is also mentioned in the White Pater of the President's Council on Bioethics in the USA that brain is not the integrator of the human body (President's Council, 2008, 40) and that body of WBD patients can have some mode of integration (President's Council, 2008, 49-68). Shewmon mentions the case of TK that survived more than

9 John Finnis changes his acceptance of the criterion of death from WBD to IHB\&BC after Shewmon's lecture (1998) (Finnis, 2011). 
14,5 years after diagnosed as brain dead (1998a, 1543; 1998b, 136). This case was confirmed after his cardiac arrest in January 2004, and the autopsy showed that his brain was destroyed and mummified (Repertinger et al., 2006). A dead brain cannot be an integrator of a human body. According to Maureen L. Condic WBD body is not integrated, because the body also needs the nervous system and especially the brain; it is only coordinated (Condic, 2016, 271). Coordination, according to Condic, is "the ability of a stimulus, acting through a specific signaling molecule, to bring responding cells into a common action or condition" and can be accomplished by either the nervous system or other bodily systems (Condic, 2016, 271). Integration is the "compilation of information from diverse structures and systems" and "during postnatal stages of human life is uniquely accomplished by the nervous systems, most especially the brain" (Condic, 2016, 271). But if the organs and tissues in a WBD body were only coordinated, they couldn't long survive. Organs for transplantation after retrieval from an organism cannot be viable for a long time (kidneys -24 hours, liver - 12-15 hours, lungs -8 hours, heart 6 - hours) (Guibert et. al. 2011, 128). ${ }^{10}$ Shewmon mentions many not-brain-mediated integrative functions e.g. homeostasis, assimilation of nutrients, elimination, detoxication and recycling of cellular wastes, energy balance, maintenance of body temperature, wound healing, fighting off infections, febrile response to infection, cardiovascular and hormonal stress responses to the incision for organ retrieval, successful gestation of a fetus, sexual maturation (Shewmon 1998b, 139-140). This allows the integration of whole brain death bodies. The second presupposition is held e.g. Patrick Lee and Germain Grisez (2012). The teaching of the Catholic Church on the soul as the form of the body, i.e. the hylomorphic conception of human beings, can be used to argue against this presupposition (Denzinger, 1991, Council of Vienne 1312, No. 902, 391). The best solution is to accept one substantial form of human being, that is human soul, as suggested by Thomas Aquinas (Thomas Aquinas, 1918, 1. 2, cap. 63, Nr. 3, 433). If a body

10 This was the main reason for changing my view from WBD (Volek, 2009) to IHB\&BD as the criterion of death in this paper. 
after WBD diagnosis can be alive for 14,5 years and if some pregnant women with WBD diagnosis were able to finish their pregnancy with viable children (Esmaeilzadeh et al., 2010), then their bodies were integrated with a human soul (Nguyen, 2018a, 233-346). The rejection of WBD as the criterion of human death is thus also coherent with the teaching of the Catholic Church. Pope John Paul II mentions the neurological criterion only once, and only hypothetically, in his address to the Transplantation Society on August 29, 2000. The presuppositions mentioned by the pope in this address are not fulfilled (Nguyen, 2017). These three presuppositions are: (1) the definitive loss of the unity of body and spirit, (2) the "clearly determined parameters commonly held by the international scientific community", (3) the rigorous application of the clinical tests (Giovanni Paolo II., 2000, No. 5, 283). The definitive loss of the unity of body and spirit can be applied only when the integration of the organism as a whole failed - this is not the case with WBD. The parameters for the determination of WBD are not the same either within the USA (Greer et al., 2008, 2016) or in the world (Wijdicks, 2006). In 2010, the American Academy of Neurology (AAN) specified Standards for Determining BD. These Standards are understood as a material for the development of policies in the US hospitals (Wijdicks et al, 2010). The rigorous application of the clinical tests is not convincing because the AAN Standards from 2010 propose tests of BSD that can cause the death of a patient with several brain injury (e.g. apnea test). This contradicts UDDA and Thomistic Christian anthropology (Nguyen 2016, 2019). There is no definitive teaching of the Catholic Church on this issue and ethicists are to form their conscience (Ostertag, and Karcher, 2019). This formation should be open to the news provided by science.

\section{(2) The higher brain death}

The proponents of HBD argue that biological death applies only to bodily integration. Since they hold that death cannot be defined biologically, but one has to focus on the moral dimension of this event, they, therefore, hold the view that death occurs with the irreversible loss of psychological functions occurring in HBD (Veatch, 2005). 
In line with this reasoning, D. Alan Shewmon says that the necessary, as well as the sufficient criterion of death, understood as passing away occurs in "the absence of both consciousness and circulation of oxygenated blood for a period of time at least up to the moment of deanimation." (Shewmon, 2010, 278). He understands deanimation as the "irreversible cessation of the organism as a whole." The necessary and sufficient criterion of deanimation is the "irreversible cessation of anti-entropic exchange of substances with the environment" (Shewmon, 2010, 281). Instead of defining "death" as such, Shewmon proposes to define the two aforementioned death-related events, namely "passing away" and "deanimation" (Shewmon, 2010, 291).

According to research conducted by Owen et al. using functional magnetic resonance imaging (fMRI), a patient in the vegetative state asked to imagine playing tennis or walking in her house had the same neural responses as healthy people asked to imagine the same thing. This points to the conclusion that people in a vegetative state have some awareness of these commands to imagine something (Owen et al., 2006, 402). In a state of deep coma or vegetative state, there are psychological processes taking place. That means HBD is not an adequate criterion of human death since the patients with $\mathrm{HBD}$, be it in a coma or vegetative state, still have or can have psychological experiences, and thus there is still life in them. Bodies with biological life are integrated, and according to Thomistic Christian anthropology, human soul remains in them, as in WBD bodies.

\section{(3) The brain stem death}

According to brain stem death view (BSD), it is sufficient to declare a man dead, when (s)he is diagnosed as BSD. Other parts of the brain can remain alive. This criterion is legal only in the United Kingdom, Canada, and India. In the UK it is adopted as an accepted medical definition of death. It was first formulated in 1976 as a criterion of death and equated with death in 1979 (Conference of Medical Royal Colleges and their Faculties in the United Kingdom, 1976, 1979). In 1995 and 2008, BSD as a criterion of death was formulated as "irreversible loss of the capacity for conscious- 
ness, combined with irreversible loss of the capacity to breathe" (Working Group of the Royal College of Physicians, 1995, 381; Academy of Medical Royal Colleges, 2008, 11) The first part of this definition of BSD is equal to HBD. This definition of BSD was criticized e.g. by D. Alan Shewmon (1998b, 132-133) and Abigail Maguire (2019). First, I will mention some of Shewmon's objections that I take to be significant. This criterion of death could also be met by someone in the state of the permanent vegetative state with diaphragmatic paralysis without their brainstem being dead. It is not clear if this concept "should require the entire brainstem to be dead or all brainstem reflexes to be absent, most of which have no bearing on either consciousness or breathing” (Shewmon, 1998b, 133). Bodies of BSD patients remain integrated because they remain integrated also in WBD, and BSD criterion is weaker than WBD. Second, according to Maguire (2019), BSD alone is insufficient for the definition of death. The main objection is that consciousness is realized by the networking between the brain stem and other regions of cortex (Medford and Critchley, 2010; Demertzi et al., 2015). The mind understood as consciousness is necessarily embodied (McMahan, $2006,47)$. In other words, in the Thomistic anthropology and according to contemporary biology, patients with BSD are somatically alive (Norkowski, 2018) and thus a rational soul is also present.

\section{(4) The controlled cardiac/circulatory death}

According to the Pittsburgh Protocol from 1992 (University of Pittsburgh Medical Center, 1993) patient or their legal guardian can decide to forgo a life-sustaining treatment. The patient can be pronounced dead after cardiac arrest and 2 minutes of asystole or ventricular fibrillation or electromechanical dissociation and confirmed by EKG and apnea and lack of responses to verbal stimuli. After the pronouncement of death, the procurement of organs for transplantation can begin. In 1967, Christiaan Barnard used this procedure in his first heart transplantation. He waited for five minutes with flat EEG and then begun the heart removal (Barnard, 1967, 1271). Bernat proposed death 75 seconds after asystole (Bernat, 2008, 671). However, 
according to medical records, there was a case when autoresuscitation occurred 33 minutes past asystole (Hornby, Hornby, and Shemie, 2010, 1246). It can thus be accepted, that the possibility of reversal exists up till 35 minutes from asystole. A man is dead only when this possibility fails/ is not present. This is conceded also by a secular bioethicist Don Marquis when he maintains that CC/CD donors are not dead (Marquis, 2010). Patient autonomy cannot serve as a ground for the acceptance of this criterion either since it is equivalent to assisted suicide. It is against the greatest value in this life, against human life. ${ }^{11}$

\section{The Dead donor rule}

Shewmon as a prominent critic of WBD surprisingly argues in favor of unpaired vital organ donation from donors after asystole (Shewmon, 1998b, 128-129; 2010, 288) similarly as Peter Singer (Singer, 2018), which violates the DDR. Shewmon proposes to replace the DDR with the "deceased donor rule" that even preserves the acronym, which requires that the removal of vital unpaired organs does not cause the donor's passing away (Shewmon, 2010, 289). ${ }^{12}$ In opposition to that, the proponents of WBD Khushf and Bernat argue that the DDR should be preserved (Khushf, 2010, 331, 356; Bernat, 2013). The reason for preserving DDR is that dying patients must be able to donate their organs voluntarily. Otherwise, they might fear that their vital unpaired organs might be removed before they are pronounced dead. Bernard and Dalle Ave also argue that the removal of organs for transplantation does not require that the condition of irreversibility be met, but that the donation has to be done after brain circulation determination of death, which can be done based on the cessation of brain

11 For the critique of all the important justifications of CC/DC see Ngyuen (2018a, 111-139).

12 David Albert Jones $(2012,138)$ interprets Shewmon $(2010,276)$ and his argument about two types of end of human life (metaphysical and civil) as confirmation of the DDR, but Shewmon's views seem to point to the opposite. The very distinction between civil end of life as sufficient for ethical and legal purposes, as well as for organ transplantation, from the metaphysical end of life as the death of organism and deanimation, and also the replacement of DDR with the deceased donor rule point to Shewmon's rejection of DDR. 
circulation and function (Dalle Ave and Bernat, 2017). As a moral duty in organ donation, DDR has been emphasized also by Popes John Paul II. ${ }^{13}$ and Benedict XVI. ${ }^{14}$

DDR should be preserved based on the value of human life which is the highest of all earthly values. Although scarifying oneself for others is a noble act, organ donation includes organ removal by the doctors, who also have to respect the value of human life. For this reason, it is unacceptable they kill human beings by removing the organs of living donors, not even if they are already in the process of dying and the donor expressed his or her consent with such procedure. The autonomy concerning the decisions about one's life has its limits set by the requirement to respect the highest value of human life. An innocent person cannot be licitly killed (except in the case of war) since among all the earthly living beings, the human being has the highest moral value. To respect DDR is to respect human life, which can also be expressed as respect for the sanctity of human life.

\section{Recommendations for the time to allow organs procurement for transplantation}

Organ procurement from death bodies is allowed only after the passing of the possibility of resuscitation. David Oderberg is right with his statement that "the bodily decomposition is a sure sign of a death", but it is problematic to see this as the only sign of death $(2019,359)$. But decomposition cannot serve as a criterion for transplantation of vital unpaired organs since the organs are not viable for transplantation after the signs of decomposition as rigor mortis have occurred. Shewmon maintains, that a waiting period of

13 "It is obvious that vital organ can only be donated after death." (Giovanni Paolo II., 1991, No. 4,1712 ) „Acknowledgement of the unique dignity of the human person has a further underlying consequence: vital organs which occur singly in the body can be removed only after death, that is from the body of someone who is certainly dead." (Giovanni Paolo II., 2000, 282)

14 „It is helpful to remember, however, that the individual vital organs cannot be extracted except ex cadavere, which, moreover, possesses its own dignity that must be respected.“ (Benedict XVI, 2008) 
"20-30 minutes following circulatory arrest would be a reasonable guess." $(1997,80)$. However, this period must be determined more precisely. Based on the comparison of the international standards, the longest waiting period after cardiac arrest for the declaration of death is set at 10 minutes in Switzerland and in the International Advisory Committee of the First International Workshop on Non-Heart- Beating Donors (NHBD) (Dhanani et al., 2012). In the scientific medical literature, we find a mention of a case, when autoresuscitation occurred 33 minutes after asystole (Hornby, Hornby, Shemie, 2010, 1246). ${ }^{15}$ Only after this time, one can acquire moral certainty that the death of a patient occurred. It is thus possible to begin the organ procurement only after 35 minutes past asystole. This time provides sufficient opportunity to gain moral certainty that the donor is dead.

\section{Conclusion}

The traditional cardiopulmonary criterion of death proved to be the only valid criterion of human death. WBD, HBD, BSD and CC/CD are not adequate criteria of human death. This thesis was justified by empirical findings combined with Thomistic Christian anthropology. In the article, I have also pointed to the need to accept the DDR. I recommend 35 minutes waiting period after the cessation of the heartbeat to begin with organ removal, which constitutes my original contribution to this topic. The waiting period is supported by empirical findings that an autoresuscitation was still recorded after 33 minutes past asystole. My contribution further lies in a systematic treatment of this issue.

Funding was providing by the grant VEGA no. 1/0637/20.

Translated by Ján Baňas

15 The most recent literature does not mention a longer period until autoresuscitation (Hornby, Dhanani, Shemie, 2018). 


\section{References}

Academy of Medical Royal Colleges. 2008. A code for practice for the diagnosis and confirmation of death. London: Academy of Medical Royal College.

Accad, Michel. 2015. "Of wholes and parts: A Thomistic refutation of 'Brain Death'." The Linacre Quarterly 82(3): 217-234.

Ad Hoc Committee of the Harvard Medical School (1968): A Definition of Irreversible Coma. Report of the Ad Hoc Committee of the Harvard Medical School to Examine the Definition of Brain Death. In: Journal of the American Medical Association 205(6): 337-340 (5.8.1968).

Austriaco, Nicanor. 2003. “Is the Brain-Dead Patient Really Dead?” Studia Moralia 41: 277-308.

Barnard, Christiaan. 1967. “The Operation. A Human Cardiac Transplant: An Interim Report of a Successful Operation Performed at Groote Schuur Hospital, Cape Town.” South Africa Medical Journal 41(48): 1271-1274. 20.12.1967.

Benedict XVI. 2008. To Participants at an International Congress Organized by the Pontifical Academy for Life. Available at: http:/vatican.va/holy_father/benedict_xvi/ speeches/2008/november/documents/hf_ben-xvi_spe_20081107_acdlife_en.html

Bernat, James L. 1998. “A defense of the whole-brain concept of death.” Hastings Center Report 28(2): 14-23.

Bernat, James L. 2006. “The whole-brain concept of death remains optimum public policy.” Journal of Law, Medicine, and Ethics 34: 35-43.

Bernat, James L. 2008. “The Boundaries of Organ Donation after Circulatory Death.” New England Journal of Medicine 359(7): 669-671.

Bernat, James L. 2013. “Life or Death for Dead-Donor Rule?” New England Journal of Medicine 369(14): 1289-1291.

Bernat, James L., Charles M. Culver, and Bernard Gert. 1981. “On the definition and criterion of death.” Annals of Internal Medicine 94: 389-394.

Bernat, James. L., Anthony M. D’Alessandro, Friedrich K. Port, Thomas P. Bleck, Stephen O. Heard, Justine Medina, Stanley H. Rosenbaum, Michael A. DeVita, Robert S. Gaston, Robert M. Merion, Mark L. Barr, William H. Marks, Howard Nathan, Kevin O’Connor, Dianne LaPointe Rudow, Alan B. Leichtman, Paul Schwab, Nancy L. Ascher, Robert A. Metzger, Virginia Mc Bride, Walter Graham, Dennis Wagner, James Warren, and Francis L. Delmonico. 2006. "Report of a National Conference on Donation after Cardiac Death.” American Journal of Transplantation 6: 281-291.

Bernat, James L., Alexander Morgan Capron, Thomas P. Bleck, Sandralee Blosser, Susan L. Bratton, James F. Childress, Michael A. DeVita, Gerard J. Fulda, Cynthia 
J. Gries, Mudit Mathur, Thomas A. Nakagawa, Cynda Hylton Rushton, Sam D. Shemie, and Douglas B. White. 2010. "The circulatory-respiratory determination of death in organ donation.” Critical Care Medicine 38(3): 963-970.

Capron, Alexander Morgan, and Leon R. Kass. 1972. "A Statutory Definition of the "Standards for Determining Human Death: An Appraisal and a Proposal." University of Pennsylvania Law Review 121(29): 87-118.

Cole, David J. 1992. “The reversibility of death.” Journal of medical ethics 18(1): 26-30.

Cole, David J. 1993. "Statutory Definitions of Death and the Management of Terminally Ill Patients Who May Become Organ Donors after Death.” Kennedy Institute of Ethics Journal 3(2): 145-155.

Condic, Maureen L. 2016. “Determination of Death: A Scientific Perspective on Biological Integration.” Journal of Medicine and Philosophy 41(3): 257-278.

Conference of Medical Royal Colleges and their Faculties in the United Kingdom. 1976. “Diagnosis of brain death.” British Medical Journal 2(6045): 1187-1188. (13.11.1976)

Conference of Medical Royal Colleges and their Faculties in the United Kingdom. 1979. “Memorandum on the diagnosis of death.” British Medical Journal 1(6159): 332. (3.2.1979)

Dalle Ave, Anne L., and James L. Bernat. 2017. "Donation after brain circulation determination of death." BMC Medical Ethics 18(15): 1-6.

De Georgia, Michael A. 2014. "History of brain death as death: 1968 to the present.” Journal of Critical Care 29: 673-678.

Demertzi, Athena, Georgios Antonopoulos, Lizette Heine, Henning U. Voss, Julia Sophia Crone, Carlo de Los Angeles, Mohamed Ali Bahri, Carol Di Perri, Audrey Vanhaudehuyse, Vanessa Charland-Verville, Martin Kronbichler, Eugen Trinka, Christophe Phillips, Francisco Gomez, Luaba Tsibanda, Andrea Soddu, Nicholas D. Schiff,Susan Whitfield-Gabrielli, and Steven Laureys. 2015. "Intrinsic functional connectivity differentiates minimally conscious from unresponsive patients.” Brain 138: 2619-2631.

Denzinger, Heinrich. 1991. Enchiridion symbolorum, definitionum et declarationum de rebus fidei et donum. Kompendium der Glaubensbekenntnisse und kirchlichen Lehrentscheidungen. Lateinisch - Deutsch. Hrsg. Von Peter Hünermann. Freiburg im Br.: Herder, 37. Aufl.

Dhanani, Sonny, Laura Hornby, Roxanne Ward, and Sam Shemie. 2012. "Variability in the Determination of Death after Cardiac Arrest: A Review of Guidelines and Statements.” Journal of Intensive Care Medicine 27(4): 238-252.

Die Deutschen Bischöfe. Die Glaubenskommision. 2015. Hirntod und Organspende. Bonn: Sekretariat der Deutschen Bischofskonferenz. 
Doran, Stephen E., and Joseph M. Vukov. 2019. “Organ Donation and Declaration of Death: Combined Neurologic and Cardiopulmonary Standards.” The Linacre Quarterly 86(4): 285-296.

DuBois, James. 1999. “Non-Heart-Beating Organ Donation: A Defense of the Required Determination of Death.” Journal of Law, Medicine \& Ethics 27: 126-136.

Erklärung der Deutschen Bischofskonferenz und des Rates der Evangelischen Kirche in Deutschland. 1990. Organtransplantationen. Bonn: Sekretariat der Deutsche Bischofskonferenz - Hannover: Kirchenamt der Evangelischen Kirche in Deutschland.

Esmaeilzadeh, Majid, Christine Dictus, Elmah Kaynvanpour, Farbod Sedaghat-Hademani, Michael Eichbaum, Stefan Hofer, Guido Engelmann, Hamidreza Fonouni, Mohammad Golriz, Jan Schmidt, Andreas Unterberg, Arianeb Mehrabi, and Rezvan Ahmadi. 2010. “One life ends, another begins: Management of a brain-dead pregnant mother. A systematic review.” BMC Medicine 8(74): 1-11. Finnis, John. 2011. “Brain Death and Peter Singer.” In Finnis, John. Intention and Identity. Collected Essays, Vol. II., 302-312. Oxford: Oxford University Press.

Gardiner, Dale., Sam Shemie, Alex Manara, and Helen Opdam. 2012. “International perspective on the diagnosis of death.” British Journal of Anaesthesia 108(S1): i14-i28.

Giacomini, Mita. 1997. “A change of heart and a change of mind? Technology and the redefinition of death in 1968." Social Science \& Medicine 44(10): 1465-1482.

Gilder, Stanley S. B. 1968. “Twenty-second World Medical Assembly.” British Medical Journal 3(5616): 493-494. (24. 6. 1968)

Giovanni Paolo II. 1991. "Ai partecipanti ad un congresso sui trapianti di organi” [To Participants at a Congress on the Organ Transplantation], 20. 6. 1991. Insegnamenti di Giovanni Paolo II. [Teachings of John Paul II.] Vol. XIV, No. 1. Vatican: Libreria Editrice Vaticana, 1710-1713.

Giovanni Paolo II. 2000. “Ai partecipanti al congresso internazionale sui trapianti” [To Participants at an International Congress on the Transplantation], 29.8.2000. Insegnamenti di Giovanni Paolo II. [Teachings of John Paul II.] Vol. XXIII, No. 2. Vatican: Libreria Editrice Vaticana, 280-285.

Gligorov, Nada. 2016. “A Defense of Brain Death.” Neuroethics 9: 119-127.

Greer, David M., Panayiotis N. Varelas, Shamael Haque, and Eelco F. M. Wijdicks. 2008.

"Variability in brain death determination guidelines in leading US neurologic institutions.” Neurology 70: 284-289.

Greer, David M., Hilary H. Wang, Jennifer D. Robinson, Panayiotis N. Varelas, Galen M. Henderson, and Eelco F. M. Wijdicks. 2016. "Variability of Brain Death Policies in the United States.” JAMA Neurology 73(2): 213-218. 
Guibert, Edgardo E., Alexander Y. Petrenko, Cecilia L. Balaban, Alexander Y. Somov, Joaquín Y. Rodriguez, and Barry J. Fuller. 2011. "Organ Preservation: Current Concepts and New Strategies for the Next Decade.” Transfusion Medicine and Hemotherapy 38: 125-142.

Hornby, Karen, Laura Hornby, Sam D. Shemie. 2010. "A systematic review of autoresuscitation after cardiac arrest.” Critical Care Medicine 38(5): 1246-1253.

Hornby, Laura, Sonny Dhanani, Sam D. Shemie. 2018. "Update of a Systematic Review of Autoresuscitation after Cardiac Arrest.” Critical Care Medicine 46(3): e268-e272.

Jonas, Hans. 1974. “Against the Stream.” In Philosophical Essays: From Ancient Creed to Technological Man, 132-140. Englewood Cliffs, New Jersey: Prentice-Hall.

Jones, David Albert. 2012. "Loss of faith in brain death: Catholic controversy over the determination of death by neurological criteria." Clinical Ethics 7: 133-141.

Kass, Leon R. 1971. “Death as an Event: A Commentary on Robert Morison.” Science 173(3998): 698-702 (20. 8. 1971).

Khushf, George. 2010. "A Matter of Respect: A Defense of the Dead Donor Rule and of a 'Whole-Brain' Criterion for Determination of Death.” Journal of Medicine and Philosophy 35: 330-364.

Kommission für Reanimation und Organtransplantation der Deutschen Gesellschaft für Chirurgie. 1968. „Todeszeichen und Todeszeitbestimmung.“ Der Chirurg 39: 196-197.

Lee, Patrick, and Germain Grisez. 2012. “Total Brain Death: A Reply to Alan Shewmon.” Bioethics 26(5): 275-284.

Lizza, John P. 2018. “Defining Death: Beyond Biology.” Diametros 55: 1-19.

Machado, Calixto. 2005. “The first organ transplant from a brain-dead donor." Neurology 64: 1938-1942.

Machado, Calixto. 2007. Brain Death. A Reappraisal. New York: Springer.

Machado, Calixto. 2019. "Further thoughts about the transatlantic divide in brain death determination." Anaesthesia 74

http://anaesthesia114.rssing.com/chan-55847669/all_p26.html\#item507

Machado, Calixto, Julius Korein, Yazmina Ferrer, Liana Portela, Maria de la C García, and José M Manero. 2007. "The concept of brain death did not evolve to benefit of organ transplants.” Journal of Medical Ethics 33: 197-200.

Machado, Calixto, Mario Estévez, Phillip A. DeFina, and Gerry Leisman. 2018. "Response to Lewis, A: Reconciling the Case of Jahi Mcmath." Neurocritical care 29: 521-522.

Maguire, Abigail. 2019. "Towards a holistic definition of death: the biological, philosophical and social deficiencies of brain stem death criteria." The New Bioethics 25(2): 172-184. 
Marquise, Don. 2010. “Are DCD Donors Dead?” Hastings Center Report 40(3): 24-31. McGee, Andrew, and Dale Gardiner. 2019. "Differences in the definition of brain death and their legal impact on intensive care practice." Anaesthesia 74(5): 569-572. McMahan, Jeff. 2006. “An Alternative to Brain Death.” The Journal of Law, Medicine, and Ethics 34(1): 44-48.

Medford, Nick, and Hugo D. Critchley. 2010. “Conjoint activity of anterior insular and anterior cingulate cortex: awareness and response.” Brain structure and function 214: 535-549.

Meisner, Joachim. 1996. „Erklärung des Erzbischofs von Köln zum beabsichtigten Transplantationsgesetz.“ Köln: Presseamt des Erzbistums Köln, Nr. 316. (27. 9. 1996)

Métraux, Alexandre. 2001. „Der Todesreigen in der belebten Materie. Xavier Bichat über das vielfache Sterben des Organismus." In: Hirntod. Zur Kulturgeschichte der Todesfestellung;, edited by Thomas Schlich and Claudia Wiesemann, 167-186. Frankfurt am Main: Suhrkamp.

Moschella, Melissa. 2019. "The human organism is not a conductorless orchestra: a defense of brain death as true biological death." Theoretical Medicine and Bioethics 40: 437-454.

Moskopp, Dag. 2017. “Brain Death: Past, Present and Future.” Journal of Intensive and Critical Care 3(3): 1-5.

National Conference on Commissioners of Uniform State Laws. 1980. Uniform Determination of Death Act.

https://www.uniformlaws.org/HigherLogic/System/DownloadDocumentFile.ashx?DocumentFileKey=341343fa-1efe-706c-043a-9290fdcfd909

Nguyen, Doyen. 2016. “Brain death and true patient care.” The Linacre Quarterly 83(3): 258-282.

Nguyen, Doyen. 2017. "Pope John Paul II and the neurological standard for the determination of death: A critical analysis of his address to the Transplantation Society”. The Linacre Quarterly 84(2): 155-186.

Nguyen, Doyen. 2018a. The New Definitions of Death for Organ Donation. A Multidisciplinary Analysis from the perspective of Christian Ethics. Bern: Peter Lang.

Nguyen, Doyen. 2018b. "Why the Thomistic defense of 'brain death' is not Thomistic: An analysis from the perspectives of classical philosophy and contemporary biophilosophy." The Thomist 82: 407-446.

Ngyuen, Doyen. 2019. "Evolution of the Criteria of Brain Death: A Critical Analysis Based on Scientific Realism and Christian Anthropology.” The Linacre Quarterly 86(4): 297-313. 
Norkowski, Jacek Maria. 2018. "Brain based criteria for death in the light of the Aristotelian-Scholastic Anthropology." Scientia et Fides 6(1): 153-188.

Oderberg, David S. 2019. "Death, unity, and the brain.” Theoretical Medicine and Bioethics 40: 359-379.

Ostertag, Christopher, and Kyle Karches. 2019. "Brain Death and the Formation of Moral Conscience.” The Linacre Quarterly 86(4): 335-346.

Owen Adrian M., Martin R. Coleman, Melanie Boly, Matthew H. Davis, Steven Laureys, and John D. Pickard. 2006. "Detecting awareness in the vegetative state.” Science 313: 1402.

Pallis, Christopher.1982. "ABC of Brain Stem Death. From Brain Death to Brain Stem Death.” British Medical Journal 285:1487-1490 (20.11.1982).

Pallis, Christopher. 1995. "Further Thoughts on Brainstem Death.” Anaesthesia and Intensive Care 23: 20-23.

Pallis, Chris. 1999. “On the Brainstem Criterion of Death.” In The Definition of Death. Contemporary Controversies, edited by Stuart J. Youngner, Robert M. Arnold, and Renie Schapiro, 93-100. Baltimore - London: The John Hopkins University Press.

President's Commission for the Study of Ethical Problems in Medicine and Biomedicine and Behavioral Research. 1981. Defining Death. A Report on the Medical, Legal and Ethical Issues in Determination of Death. Washington, DC: US Government Printing Office.

President's Council on Bioethics. 2008. Controversies in the Determination of Death. A White Paper by the President's Council on Bioethics. Washington, DC: www. bioethics.gov.

Repertinger, Susan, William P. Fitzgibbons, Matthew F. Omojola, and Roger A. Brumback. 2006. "Long Survival Following Bacterial Meningitis-Associated Brain Destruction.” Journal of Child Neurology 21(7): 591-595.

Seifert, Josef. 1993. “Is ‘Brain Death’ Actually Death?” The Monist 73:175-202.

Shemie, Sam D., Christopher Doig, Bernard Dickens, Paul Byrne, Brian Wheelock, Graeme Rocker, Andrew Baker, T. Peter Seland, Cameron Guest, Dan Cass, Rosella Jefferson, Kimberly Young, Jeanne Teitelbaum, on behalf of Pediatric Reference Group and the Neonatal Reference Group. 2006. "Brain arrest: the neurological determination of death and organ donor management in Canada." Canadian Medical Association Journal 174(6): S1-S30 (14.3.2006).

Shemie, Sam D., Laura Hornby, Andrew Baker, Jeanne Teitelbaum, Sylvia Torrance, Kimberly Young, James L. Bernat, Luc Noel, and The International Guidelines for Determination of Death phase 1 participants, in collaboration with the World Health Organization. 2014. "International guideline development for the determination of death.” Intensive Care Medicine 40: 788-797. 
Shewmon, D. Alan. 1985. "The Metaphysics of Brain Death, Persistent Vegetative State, and Dementia.” The Thomist 49(1): 24-80.

Shewmon, D. Alan. 1997. “Recovery from ‘Brain Death’: A Neuorologist’s Apologia.” The Linacre Quarterly 64(1): 30-96.

Shewmon, D. Alan. 1998a. “Chronic 'brain death'. Meta-analysis and conceptual consequences.” Neurology 51: 1538-1545.

Shewmon, D. Alan. 1998b. “'Brainstem Death,' 'Brain Death' and Death: A Critical Re-Evaluation of the Purported Equivalence." Issues in Law and Medicine 14(2): 125-145.

Shewmon, D. Alan. 2001. "The Brain and Somatic Integration: Insights Into the Standard Biological Rationale for Equating ‘Brain Death' With Death.” Journal of Medicine and Philosophy 26(5): 457-478.

Shewmon, D. Alan. 2010. "Constructing the death elephant: a synthetic paradigm shift for definition, criteria, and tests for death." Journal of Medicine and Philosophy 35: 256-298.

Shewmon, D. Alan. 2018. “The Case of Jahi McMath. A Neurologists View.” Hastings Center Report 48(S4): S74-S76.

Schiff, Nicholas D. and Joseph J. Fins. 2016. "Brain death and disorders of consciousness.” Current biology 26: R572-R576.

Singer, Peter. 1974. “All Animals Are Equal.” Philosophical Exchange 1: 103-116.

Singer, Peter. 1994. Rethinking Life and Death. The Collapse of Our Traditional Ethics. New York: St. Martin Griffin.

Singer, Peter. 2011. Practical Ethics. Third ed. Cambridge: Cambridge University Press. Singer, Peter. 2018. "The Challenge of Brain Death for the Sanctity of Life Ethic." Ethics \& Bioethics (in Central Europe) 8(3-4): 153-165.

Smith, Martin. 2015. “Brain Death: The United Kingdom Perspective.” Seminars in Neurology 35: 145-151.

Sulmasy, Daniel P. 2019. "Whole-brain death and integration: realigning the ontological concept with clinical diagnostic tests.” Theoretical Medicine and Bioethics 40: 455-481.

Thomas Aquinas. 1918. Summa contra gentiles. Opera omnia iussu edita Leonis XIII P. M. Romae: Typis Riccardi Garrone.

Truog, Robert D. 2007. "Brain death - Too Flawed to Endure, too Ingrained to Abandon.” Journal of Law, Medicine and Ethics 35(2): 273-281.

University of Pittsburgh Medical Center. 1993. "University of Pittsburgh Medical Center Policy and Procedure Manual.” Kennedy Institute of Ethics Journal 3(2): A-1-15. 
Vadi, Sonali and Sunil Shroff. 2019. "Redefining Death. Urgent Need to Evolve toward a Homogenous Definition of Death in India.” Indian Journal of Critical Care Medicine 23(8): 368-370.

Veatch, Robert. M. 2005. "The Death of the Whole-Brain Death: The Plague of Disaggregators, Somaticists, and Mentalists." Journal of Medicine and Philosophy 30: 353-378.

Volek, Peter. 2009. Určenie smrti človeka a darcovstvo orgánov. [Determination of Death and Organ Donation] Ružomberok: Katolícka univerzita v Ružomberku, Filozofická fakulta.

Wijdicks, Eelco, F. M. 2001. “The Diagnosis of Brain Death.“ New England Journal of Medicine 344(16): 1215-1221 (19.4.2001)

Wijdicks, Eelco F. M. 2006. "The clinical criteria of brain death throughout the world: why has it come to this?" Canadian Journal of Anesthesia 53(6): 540-543.

Wijdicks, Eelco F. M., Panayiotis N. Varelas, Gary S. Gronseth, and David M. Greer. 2010. "Evidence-based guideline update: Determining brain death in adults. Report of the Quality Standards Subcommittee of the American Academy of Neurology.” Neurology 74(23): 1911-1918.

Working Group of the Royal College of Physicians. 1995. "Criteria for the Diagnosis of Brain Stem Death: Review by a Working Group Convened by the Royal College of Physicians and Endorsed by the Conference of Medical Royal Colleges and their Faculties in the United Kingdom." Journal of the Royal College of Physicians of London 29(5): 381-382. 